\title{
THE PRINCIPLES OF FINANCIALLY RELEVANT PROMOTION OF WORK WELL-BEING - A FINNISH PERSPECTIVE
}

\author{
G. Ahonen ${ }^{1 *}$ \\ ${ }^{1}$ Hanken School of Economics, Helsinki, Finland \\ *Corresponding email: guy.ahonen@professori.fi
}

Received: 2 September 2020; Accepted: 25 September 2020

Cite as: Ahonen, G. (2020). The principles of financially relevant promotion of work well-being - a Finnish perspective. Labour Protection Problems in Ukraine, 36(3), 3-9.

Despite abundant research indicating that promotion of work well-being is basically profitable for the corporations, the management in many organizations fails to see the financial potential of improving the working conditions of their personnel. The purpose of this paper is to present recent findings on the financial effects of work well-being activity mainly in Finland, and extract five success principles in this context. This study is based on a number of empirical studies in which the author of this article has participated during the past decade and similar studies in Finland and other countries. The main focus is on the relationship between activities which promote work well-being and their financial consequences for the employers. Particularly the findings generated by the decadelong Finnish strategic well-being-project are exploited. Survey data from more than 2000 randomized Finish private and public organizations were collected and analyzed. Finnish cases indicate that companies can benefit up to $20 \%$ of their profits by investing in their personnel. Comprehensive Finnish surveys indicate that the management of work well-being is far from optimal and that companies that take well care of their people do financially well. It is maintained that companies have a limited view of the scope and possibilities of work well-being activity and therefore fail to see its financial potential. The main limitation of this study is that it is based on mainly Finnish and Nordic data and research. This means that some of the cost structures of the companies studied may vary from those of companies in other countries. The magnitude of the financial effects is, however, so large that the findings should be indicative for other countries as well. The practical value of the principles generated and presented in this paper is in that they demonstrate the mechanisms of how promotion of safety and well-being at work is transformed into financial value. That may help public and private policymakers in developing national and company-level human resource strategies. The findings add to the literature of the economic feasibility of occupational safety and health by introducing new explanations to how the economic effects emerge.

Keywords: occupational safety and health; workplace health promotion; work well-being; productivity; economic feasibility; human resource management.

\section{ПРИНЦИПИ ПОСИЛЕННЯ ФІНАНСОВОГО СПРИЯННЯ БЛАГОПОЛУЧЧЮ НА РОБОТІ - ПОГЛЯД ФІНЛЯндІї}

\section{Г. Ахонен ${ }^{1^{*}}$}

${ }^{1}$ Школа економіки Ханкена, Гельсінкі, Фінляндія

*E-mail для листування: guy.ahonen@professori.fi

Отримано: 2 Вересня 2020; Прийнято: 25 Вересня 2020

Цитувати як: Ahonen, G. (2020). The principles of financially relevant promotion of work well-being - a Finnish perspective. Labour Protection Problems in Ukraine, 36(3), 3-9.

Незважаючи на численні дослідження, які свідчать про те, що сприяння благополуччю на роботі в основному вигідно для корпорацій (організацій, установ), керівництво багатьох із них не бачить фінансового потенціалу поліпшення умов праці своїх співробітників. Мета статті надати нещодавно отримані висновки про фінансові наслідки діяльності, пов'язаної з благополуччям на роботі, в основному в Фінляндії, виділити п'ять принципів успіху в цьому контексті. Це дослідження засноване на ряді емпіричних досліджень, в яких автор статті брав участь протягом останнього десятиліття, а також на аналогічних дослідженнях як у Фінляндії, так і в інших країнах. Основна увага приділяється взаємозв'язку між діяльністю, що сприяє благополуччю на роботі, і її фінансовими наслідками для роботодавців. Зокрема, використовуються результати десятирічного фінського проєкту стратегічного благополуччя. Були зібрані та проаналізовані дані опитувань керівників більше ніж 2000 рандомізованих приватних і державних організацій Фінляндії. Отримані дані показують, що компанії можуть отримати до 20 \% прибутку, інвестуючи в свій персонал. Комплексні опитування в Фінляндії свідчать, що управління добробутом на робочому місці не є оптимальним і що компанії, які добре піклуються про своїх співробітників, досягають більшого успіху у фінансовому відношенні. Стверджується, що деякі компанії мають обмежене уявлення про масштаби і можливості діяльності щодо забезпечення благополуччя на роботі і тому не бачать ії фінансового потенціалу. Основним обмеженням цього дослідження є те, що воно засноване в основному на даних досліджень фінських і інших північноєвропейських країн. Це означає, що деякі структури витрат досліджених компаній можуть відрізнятися від структур компаній в інших країнах. Однак масштаби фінансових наслідків настільки великі, що результати можуть бути показовими і для країн, де не проводилось дослідження. Практична цінність принципів, сформульованих і представлених у цьому документі, полягає в тому, що вони демонструють механізми того, як сприяння безпеці та добробуту на роботі трансформується у фінансову цінність. Це може допомогти державним і приватним особам, які визначають політику корпорації (організації, установи) в розробці кадрових стратегій на національному рівні та на рівні компаній Отримані результати доповнюють літературу про економічну доцільність забезпечення безпеки і гігієни праці, надаючи нові пояснення того, як виникають економічні ефекти.

Ключові слова: охорона праці; зміцнення здоров'я на робочому місці; гарне самопочуття на роботі; продуктивність; економічна доцільність; управління людськими ресурсами.

1. Problem statement and analysis of the recent researches and publications.

In many companies the economic potential of work wellbeing activity is not realized and exploited $[1,2]$. One of the reasons is that work well-being activity is viewed as merely a cost factor $[1,2]$. It is also considered to be a peripheral activity, not belonging to the core activities of the company [3].

Despite abundant research indicating that promotion of work 
well-being is basically profitable for the corporations [4-6], the management in most organizations fails to see the financial potential of improving the working conditions of their personnel. Finnish cases indicate that companies can benefit up to $20 \%$ of their profits by investing in their personnel $[7,8]$. The purpose of this paper is to present recent findings on the financial effects of work well-being activity mainly in Finland. Finland has a long tradition of comprehensive work ability promotion [9-11]

Promotion of work well-being activity can have a narrow or a more comprehensive meaning. In its most narrow sense it means occupational health services and occupational safety. In the most comprehensive approach it includes all aspects of personnel-well-being. In Finland so-called management of work-ability (MVA) has been the dominant approach and internationally the most comprehensive form of promotion of work well-being. Initially, MWA was characterized by an emphasis on physical exercise and other individual factors [11]. Physical exercise has been considered an important factor in improving work ability because it has documented positive physical effects [12] and increases mental resources [13]. Eventually the psychological and community aspects became more dominant [14]. The most recent approach is based on managing so-called strategic well-being, which includes all those aspects of personnel well-being which affect the employers financial performance [15]. In the following we discuss the financial effects of all kinds of work well-being activity.

\section{Statement of the problem and its solution.}

2.1 Materials and methods.

This study is based on a number of empirical studies carried out in Finland during the past decade and similar studies in other countries. The main focus is on the relationship between activities which promote work wellbeing and their financial consequences for the employers. Particularly the findings generated by the decade-long Finnish strategic well-being-project are exploited. In this project survey data from more than 2000 randomized Finish private and public organizations were collected and analyzed. To make the reasoning managerially useful the presentation is made in terms of a set of principles which are conducive to financially feasible promotion of work well-being.

\subsection{Results and Discussion.}

2.2.1. Principle 1: Occupational safety and health activity reduces costs.

Cost reduction is the most obvious mechanism by which work well-being activity is justified for the company management. On the other hand, it is doubted by a great number of company leaders and managers. In their report on Calculating the International Return on Prevention for Companies: Costs and Benefits of Investments in Occupational Safety and Health [1] authors note that $24 \%$ of company managers in 300 companies all over the world think investments in occupational safety and health increases the costs of the company.

On the other hand, $50 \%$ of managers consider $\mathrm{OSH}$ activity beneficial from a cost reduction point of view. Other studies support this finding. In study [6] Chapman for instance found that sick-leaves were reduced by in average $26.8 \%$, health care costs by $26.1 \%$ and insurance costs by $32 \%$ in 50 successful intervention projects. In a Finnish paper industry study the sick-leave reduction was found to be associated with the level of measured work-ability, stress level, worker co-operation, co-worker support and perceived justice of managers [17]. In study [6] Chapman found an average benefit/cost ration of 5.8 for well conducted work health promotion intervention studies. This ratio was also discovered in a Finnish study conducted among 70 Finnish companies [2]. One could wonder why these quite impressive results do not have more extensive impact on manager attitudes. One answer could be that the OSH interventions are financially relatively small compared to the overall economic activity of the firms. Another explanation is the widespread core activity approach that many strategic managers and developers have adopted [17].

2.2.2. Principle 2: Work well-being is part of the intangible assets of the firm.

Although the cost-reducing effect is the most obvious economic justification of OSH activity, it is not the most important. Since the late 1990s it has been known that the most important driver of economic success is not the tangible but the intangible assets of the firm [18]. By the intangible assets are meant the human capital, the structural capital and the relational capital of the firm [19]. Another way to put it is to call these assets the competence of the personnel, the internal structure and the external structure (Figure 1).

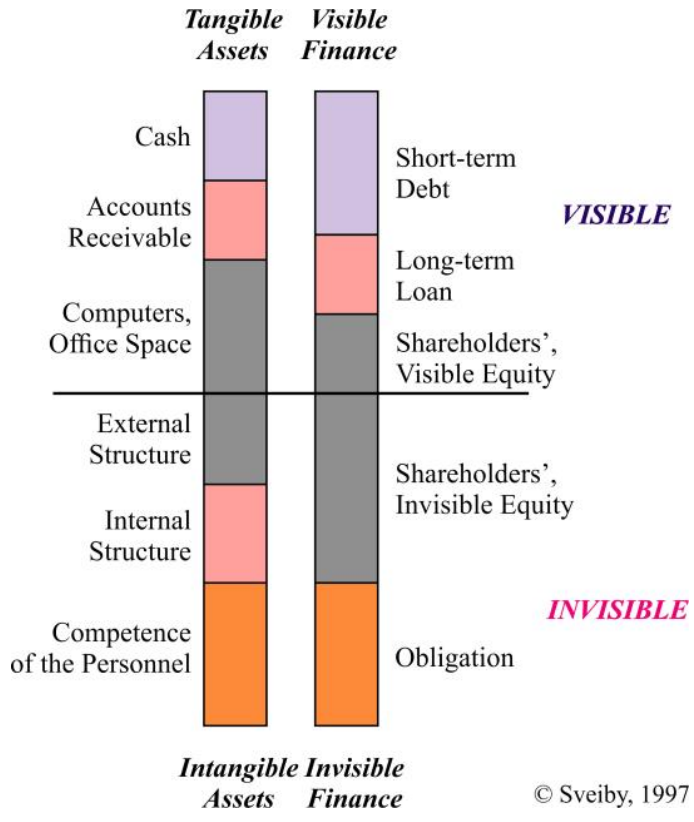

Figure 1 - The structure of the real balance sheet of a knowledge company [18]

During the industrial era the financial value of the company was basically equal to the equity value of the firm, or the difference between the tangible assets and the debts and loans. In the knowledge-era the company value usually by far exceeds the so-called book-value. This so-called brand-value or invisible equity was at the last turn of the century more than 7 times the equity value for listed companies. Since then it has stabilized close to 4 [20].

What makes intangible assets so interesting from a work well-being point of view is that all the intangibles have to do with people, one way or the other (Figure 2).

Management of work ability (MWA) is highly knowledgerelevant, which is not always acknowledged. It is obvious that work ability is connected to human capital, indicating that the individual's health also has an effect on the total value of the company. However, work ability has linkages also to the other two forms of capital. In his work [21] Ahonen demonstrated that human capital related intangibles can determine all other kinds of intangibles. 


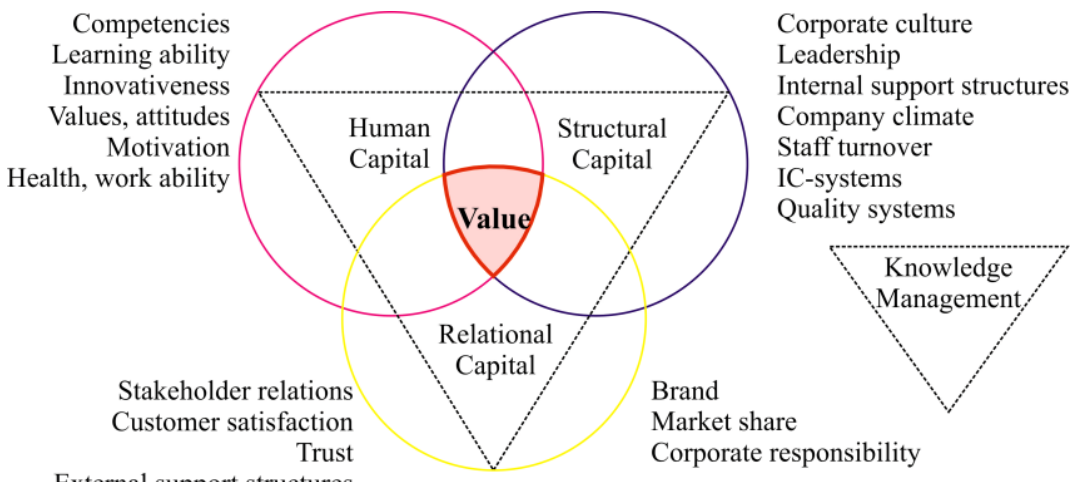

External support structures

Figure 2 - Elements of work-ability in intangible assets

At the same time in work [14] Hussi has demonstrated the close relationship between the Finnish MWA practice and IC (that is intellectual capital or intangible assets). The relationship forms the following matrix (Figure 3).

\begin{tabular}{|l|c|c|c|}
\hline \multicolumn{1}{|c|}{ MWAIIC } & HC & SC & RC \\
\hline Individual health & $*$ & & $*$ \\
\hline Competence & $*$ & & $*$ \\
\hline Work environment & & $*$ & $*$ \\
\hline Work community & & $*$ & $*$ \\
\hline
\end{tabular}

Figure 3 - The compatibility of MWA and IC in Finland

The work community contains the values and the culture of the company, which influence knowledge sharing, that is, structural capital. The work environment includes basically the physical conditions of work, including its ergonomic qualities. It facilitates communication and cooperation, which makes it intangible, and a part of structural capital. Relational capital is dependent on work ability. People have to be reasonably healthy and possess certain knowledge in order to be able to maintain good external contacts. As customer relations become increasingly complex, a decreasing part of working tasks can be performed in isolation. This development puts significant pressures on the effective functioning of the work community. A well-organized work environment is also a prerequisite of relational capital. However, these ideas have not been commonly presented in the work ability literature. In brief, it can be argued that work ability forms a well-defined framework for factors that exert crucial influence on the IC of the company.

The asterisks in the grid above (Figure 3) indicate conceptual similarities between both concepts. Competence can be seen as identical to the definitions on human capital. However, as has been shown, health is also the characteristic of an individual and is relevant when considering productive capacity. Therefore, this extension is highly relevant. Like competence and human capital, work environment and work community are included in structural capital by definition.

The intangible nature of OSH has implications for how modern companies view the role of occupational safety. Instead of calculating the costs of safety activity, many companies regard safety as an aspect of building the brand of the company. A high quality and reliability of the production process can elevate the customers' willingness to pay, which increases the sales revenues of the company (Figure 4).

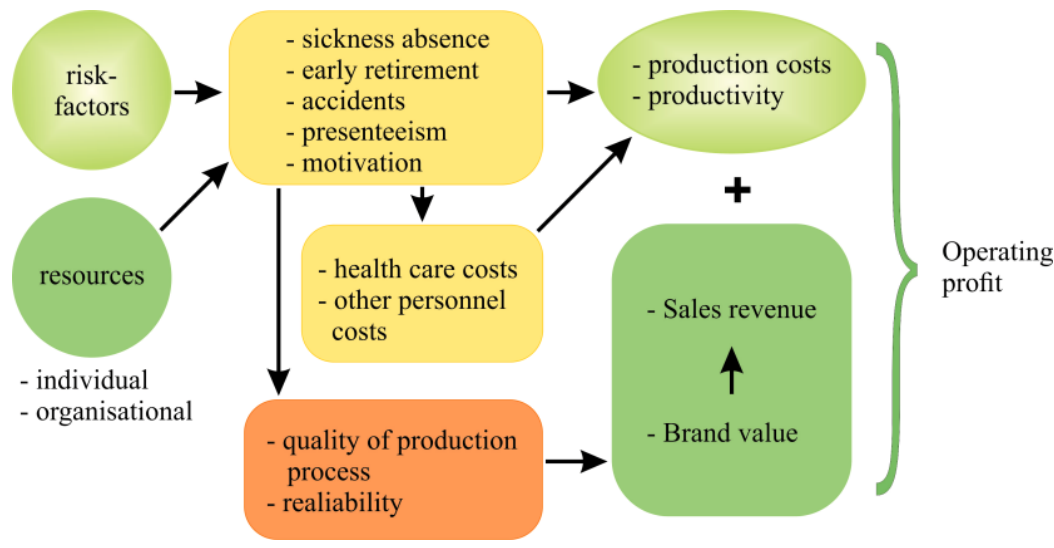

Figure 4 - The new financial logic of occupational safety

\subsubsection{Principle 3: A Value-based approach - not} transaction based.

For a number of years a research project [2] supported by the Finnish employers association has been conducted to establish the cost of so-called undone work, which includes the cost of sickness absenteeism, early retirement fees, accident insurance fees and occupational health service costs. An analysis of 70 companies of all sizes revealed, that there was a considerable spread of these costs related to total personnel costs. They varied between 2 and $14 \%$. Ten of these companies adopted so called value-based management of personnel work ability. These companies were compared with similar companies with a different work ability management and with the rest of the companies. The analysis showed that the companies pursuing the value-based strategy were much more successful in reducing total personnel costs than the two other groups. 
The value-based approach to personnel health management vas originally invented by Porter and Teisberg in 2006. In the Finnish case it means a system were the management of the personnel health is based on a detailed and up-to-date information and reporting system, with strict quantitative goals and clear managerial responsibilities. Most importantly, the value-based strategy concentrates on the financial value created and lost in the company, not on the direct cost of occupational health care, which is typical for the so-called transaction-based approach.

Most astonishingly, the value-based approach often requires bigger $\mathrm{OSH}$-investments than the transaction-based approach, but leads to lower total personnel costs. Also, surprisingly, the value-based approach leads to a $6 / 1$ benefitcost ratio, when comparing the marginal OSH input costs and the equivalent cost savings [2].
2.2.4. Principle 4: Personnel productivity - not only cost reduction.

In an annually conducted study of totally 2000 Finnish companies and public organizations in years $2009-2016$ the nature of personnel measures was explored [22]. The study revealed that a majority of the measures could be classified as cost reducing, and a minority as productivity enhancing (Figure 5). The trend remained constant over the years. This is unfortunate, as it has been demonstrated that the financial potential of productivity enhancing measures is manyfold compared to cost reducing activity [15].

To get a more realistic picture of the financial significance of work health activity the Nordic Council of Ministers conducted a register-based study in four Nordic countries to estimate the relationship between working environment and productivity was conducted [23]. The basic model is described in Figure 6.

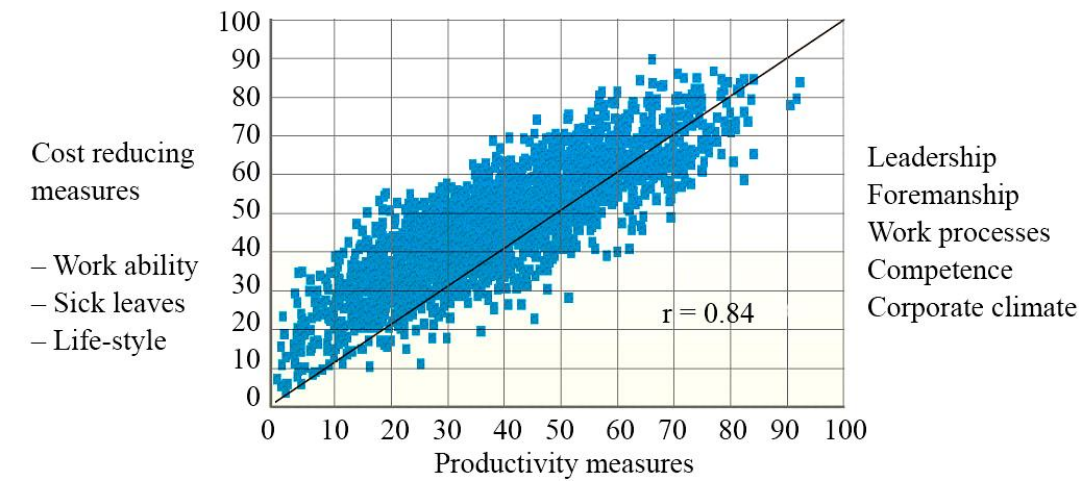

Figure 5 - Cost reducing and productivity enhancing measures in Finnish organizations 2009 - 2016 [22]

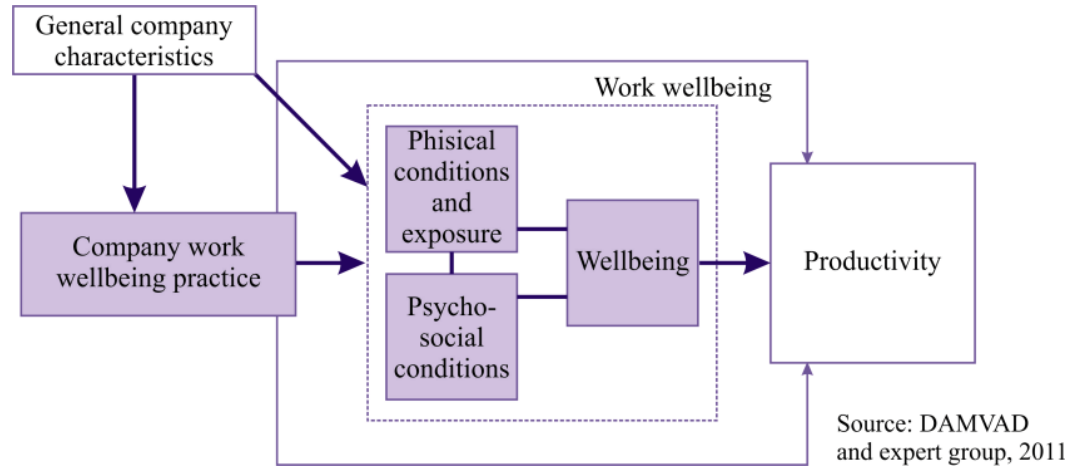

Figure 6 - Overall model for company practice, work wellbeing and productivity [23]

The data was originally collected for other purposes and, thus, the analyses was seen as a first take on testing whether or not there is indeed a relationship between working environment and productivity (and whether or not it is a positive one). It was stressed by the researchers that a nonresult does not equal a negative result. The main result of the report was that physical working environment is an important, statistically significant predictor of productivity. This result is robust to various empirical specifications in Denmark and Sweden, the two countries in which national data protection regulations do not prohibit the matching of individual-level information on working environment with company level information on productivity and other company-level characteristics, and thus allowed to harmonize data at individual level.

In Norway and in Finland it was also identified that physical working environment is an important, statistically significant predictor of productivity. However, in Norway and in Finland data regulations prohibit the matching of information on individual-level working environment and company level performance. Therefore, the analysis was performed at sector level and showed similar results.

In Sweden and in Denmark, only in one case a positive relationship between psychosocial working environment and productivity was found. This is a somewhat surprising result, as factors such work-life imbalances and work-related "stress" are included in the concept of psychosocial working environment as defined here - and since it is easy to see how work-related "stress" could affect and hamper productivity.

The result might be explained with the level at which data is collected. Psychosocial working environment is closely related to the individual person, whereas physical working environment is related to groups within the company or the whole company. There might be huge variation in personal perceptions of psychosocial working environment, but at company level the differences even out. Thus, a non-result here 
cannot be interpreted as a negative result, but as much a question of how data is collected. Thus, a correlation between psychosocial working environment and productivity can neither be confirmed nor rejected.

In 2015 a study on the relationship between the personnel productivity factors (PPF) and the operating profit of the company was conducted in Finland [24]. The study was made possible by company climate data obtained from a Finnish pension fund (Etera) and accounting data from the Ministry of Finance registers. Three factors were discovered to determine personnel productivity: work motivation, experienced level of competence and measured work ability. On basis of these factors a personnel productivity index (PPI) was constructed.

The analysis was made for middle-sized companies in the construction sector to control for size and sector variation. The results showed that the PPI correlated positively with the operating profit of the companies. Divided into three groups the companies in the highest third of the PPI had an about three times higher annual operating profit per person $(14000 €)$ than those in the lowest third $(5000 €)$. Extended to the national level it could be determined that the Finnish private sector loses annually 9 billion euro in operating profits because of poor people management and consequent insufficient personnel productivity. This renders an almost $20 \%$ unexploited productivity potential in the Finnish private sector. The data also revealed that the financial potential of productivity promotion is 7 -fold compared to cost reduction [15].

In order to establish the relationship between the personnel productivity factors and management of strategic well-being (MSW), questions related to motivation, professional competence and work-ability of the personnel, the supportiveness of the organizational climate and level of foremanship were added to the 2016 MSW survey. Based on earlier surveys and the new data an estimate of the personnel productivity index was generated. Regression analysis showed that personnel productivity was positively correlated with the MSW index and the level of foremanship [22].

The MWS and PPI-studies indicate that companies can by adopting good people management considerably improve their value creation. This supports the view that people matter in the value creation process.

Sometimes the financial effects can come about in a very indirect way. In a comprehensive study of the effects of promoting work ability in small and medium-sized enterprises in Finland it was found that the productivity effects of work ability promotion activity could not always be detected although the effect was profitable [25].
2.2.5. Principle 5: Strategic well-being - not well-being in general.

In order to study work well-being activity from a business point of view, Aura et. al. in work [26] developed the Management of strategic well-being concept, which was operationalized into a survey questionnaire.

The MSW surveys $[15,26]$ cover randomly chosen companies from seven main branches of industry of all sizecategories in Finland. About 400 organizations replied annually to the questionnaire, representing the state, the municipal sector, manufacturing, construction, retail, transport and logistics and business services. The response-rate was $48.5 \%$. The questionnaire includes 41 separate questions and 181 answer-items.

The level of the management of strategic well-being was measured by the MSW-index, which covers all areas of activity aimed at managing strategic well-being. The index ranges between 0 and 100 . In 2014 its value was 51, which is clearly above the 2009 - 2012 level $(41-47)$. Hence, the level of MSW has increased during the whole range of study years in Finland.

The MSW consists of four sub-areas (Figure 7):

- The strategic base of strategic wellbeing;

- The role of well-being in management activities;

- Foremanship and HR-activities;

- The work-well-being support-activities.

The data demonstrates that subjectively evaluated economic performance of the company correlates significantly positively with the MSW-index (Figure 8). This finding justifies the use of MSW model as a financially relevant framework for managing work well-being activity in organizations.

The positive development of the MSW index is mainly explained by the changes in management, HR and foreman behaviour during 2009 - 2016. The organizations have more clearly and with more articulated aims defined what to do. Accordingly, work-wellbeing has increasingly become a part of management and HR-activities. In addition, an increasing number of foremen have become responsible for the well-being of their subordinates. There has been progress in most branches of industry and all organizational size-categories.

The amount of MSW investments in Finland were estimated for the sixth time in 2016 . It was $796 €$ per person per year and 1.8 Billion $€$ for the whole economy, which is about $2 \%$ of the total personnel costs of the economy. The data shows that the economic state of the organization is clearly reflected in the MSW investment level: economically very successful organizations invest more than $1000 €$ per person per year, economically poor organizations invest only 500-600. Altogether the level SW investments is modest compared to for instance the estimated annual loss of 24 Billion $€$, due to loss of work ability [27].

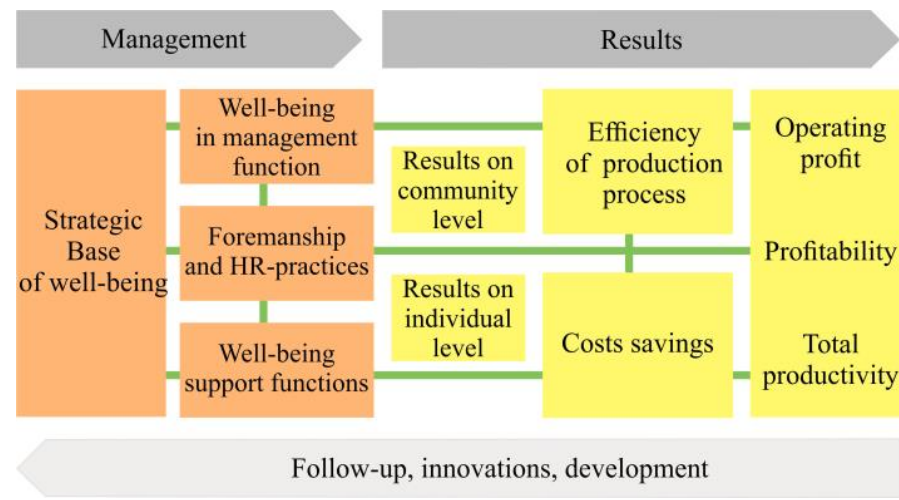

Figure 7 - The Management of strategic well-being (MSW) model [15] 
Economic performance, $\%$
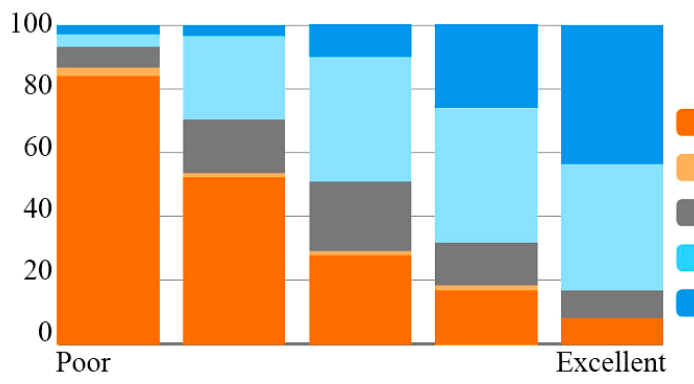

no information

worse performance

unchanged performance

slightly improved performance

excellent performance

Figure 8 - MSW-index and subjectively evaluated economic performance of Finnish organizations 2009 - 2016 [22]

\subsubsection{Discussion.}

The main limitation of this study is that it is based on mainly Finnish and Nordic data and research. This means that some of the cost structures of the companies studied may vary from those of companies in other countries. The magnitude of the financial effects is, however, so large that the findings should be indicative for other countries as well. The practical value of the principles generated and presented in this paper is in that they demonstrate the mechanisms of how promotion of safety and well-being at work is transformed into financial value. That may help public and private policymakers in developing national and companylevel human resource strategies.

The findings add to the literature of the economic feasibility of occupational safety and health by introducing new explanations to how the economic effects emerge.

\section{Conclusion.}

It has been demonstrated by numerous systematic reviews and singular studies that promotion of and investment in work health and well-being can be financially very beneficial for companies [4-6]. The above discussion has demonstrated that there are a few simple principles that render well conducted work well-being activity economically feasible. To repeat, these principles are:

1. Occupational safety and health activity reduces costs;

2. Work well-being is part of the intangible assets;

3. Value-based approaches should be preferred to transaction-based;

4. Personnel productivity rather than cost reduction;

5. Strategic well-being - not well-being in general.

By considering these principles, any organization can turn the financial potential of work well-being into real financial returns. Together these principles demonstrate that by adopting a systematic and comprehensive approach to work well-being a company can increase its financial performance up to a fifth of its normal standard.

\section{Acknowledgements.}

We are gratefully acknowledged to Hanken School of Economics (Helsinki) and the Editorial Board of Labour Protection Problems in Ukraine.

\section{REFERENCES}

1. Braunig, D., Kohstall, T. (2013). Calculating the international return on prevention for companies: Costs and benefits of investments in occupational safety and health. International Social Security Association. Geneva. Available: https://ww1.issa.int/sites/default/files/documents/ publications/2-ROP-FINAL_en-157255.pdf.

2. Työkykyjohtamisen benchmark-tutkimus 2014. Loppuraportti 15.10.2014. Available: https://www.terveystalo.com/Global/tth/Tekem\%C3\% A4tt\%C3\%B6m\%C3\%A4n\%20ty\%C3\%B6n\%20vuosikatsaus\%202014\%20loppuraportti.pdf.

3. Jain, A., Leka, S., Zwetsloot, G.I. (2018). Managing health, safety and well-being: Ethics, responsibility and sustainability. Springer. Dordrecht.

4. Lerner, D., Rodday, A. M., Cohen, J.T., Rogers, W.H. (2013). A systematic review of the evidence concerning the economic impact of employee-focused health promotion and wellness programs. Journal of Occupational and Environmental Medicine, 55(2), 209-222.

5. Baicker, K., Cutler, D., Song, Z. (2010). Workplace wellness programs can generate savings. Health affairs, 29(2), 304-311.

6. Chapman, L.S. (2005). Meta-evaluation of worksite health promotion economic return studies: 2005 update. American Journal of Health Promotion, 19(6), 1-11. DOI: 10.4278/0890-1171-19.4.TAHP-1.

7. Parvinen, L.A., Windischhofer, R., Gustafsson, M. (2010). Competitive advantage through value-based health care: The case of Metso Corporation. European Management Journal, 28(3), 195-207.

8. Ahonen, G., Parvinen, L., Vainio, H., Husman, K., Ylikoski, M., Parvinen, A., Liira, J., Puputti, I., Parry, S. (2011). Arvopohjainen työkyvyn hallinta tehostaa työterveyshuoltoa-Kahden yrityksen tapauskuvaus. Suomen Lääkärilehti, 66(11), 921-926.

9. Johanson, U., Ahonen, G., Roslender, R. (2007). Work health and management control. Stockholm: Thomson fakta. Available: https://www.researchgate.net/profile/Ulf_Johanson/publication/257871940_Work_health_and_management_control//inks/54119d2f0cf29e4a2329709 7.pdf.

10. Ilmarinen, J. (2006). Towards a longer working life! Ageing and the quality of worklife in the European Union. Finnish Institute of Occupational Health (FIOH), Helsinki.

11. Jurvansuu, S., Seitsamo, J., Tuuli, P. (2000). Toimipaikan menestyminen, organisaation terveys ja henkilöstön hyvinvointi. In K. Tuomi (Ed.) Yrityksen menestyminen ja henkilöstön hyvinvointi. Työ ja ihminen tutkimusraportti, 15. Työterveyslaitos, Helsinki

12. Aura, O. (2006). Worksite fitness policy in an intellectual capital framework. Swedish School of Economics and Business Administration, Economics and Society, 164, Helsinki. Available: https://helda.helsinki.fi/bitstream/handle/10227/229/164-951-555-935-9.pdf? sequence=2\&is Allowed=y.

13. Ilmarinen, J. (1995). Työkykyä edistävät ja heikentävät tekijät. Julkaisussa: Rautoja, S.(toim.). Hyvä työkyky: työkyvyn ylläpidon malleja ja keinoja. Työterveyslaitos. Helsinki.

14. Hussi, T. (2005). Essays on managing knowledge and work related wellbeing. Swedish School of Economics and Business Administration, Economics and Society, 150, Helsinki. Available: https://helda.helsinki.fi/bitstream/handle/10227/122/150-951-555-892-

1.pdf? sequence $=2 \&$ is Allowed $=\mathrm{y}$.

15. Aura, O., Ahonen, G. (2016). Strategisen hyvinvoinnin johtaminen. Helsinki: Talentum Pro. Helsinki.

16. Pahkin, K., Leppänen, A., Kajosaari, K., Ala-Laurinaho, A., Welling, I., Väänänen, A., Joensuu, M., Koskinen, A. (2010). Työhyvinvoinnin kehittäminen ja sairauspoissaolojen hallinta paperiteollisuudessa. Työympäristötutkimuksen raporttisarja, 48, Finnish Institute of Occupational Health (FIOH), Helsinki 2010 
17. Galabova, L., Ahonen, G. (2011). Is intellectual capital-based strategy market-based or resource-based?. Journal of Human Resource Costing \& Accounting, 15(4), 313-327. DOI: 10.1108/14013381111197243.

18. Sveiby, K.E. (1997). The new organizational wealth: Managing \& measuring knowledge-based assets. Berrett-Koehler Publishers. 220 p. Available: https://books.google.com.ua/books?hl=ru\&lr=\&id=xKNXlgaeCjAC\&oi=fnd\&pg=PR9\&ots=9XEhbqx496\&sig=iOhFUfR7En2xXNPTqx BBXLCPXZA\&redir_esc $=\mathrm{y} \# \mathrm{v}=$ onepage $\& \mathrm{q} \& \mathrm{f}=$ false.

19. MERITUM 2002: Cañibano Leanadro, Sánches M Paloma, Garcia-Aysuo Manuel, Chaminade Cristina (eds.): Guidelines for managing and reporting on intangibles (Intellectual Capital Report). Dundatión Airtel Móvil. Vodafone. Madrid 2002.

20. Roberts, L. Update On Market Overvaluations_- $43 \%$ to $90 \%$ Above Historic Means. Another Measure Of Overvaluation. Available: https://www.davidstockmanscontracorner.com/update-on-market-overvaluations-43-to-90-above-historic-means/.

21. Ahonen, G. (2000). Generative and commercially exploitable intangible assets. Classification of intangibles, (712), 206-213.

22. Aura, O., Ahonen, G., Hussi, T., Ilmarinen, J. (2014). Strategisen hyvinvoinnin tila Suomessa. Excenta Oy. Helsinki 2009 and 2010 (Excenta and Finnish Institute of Occupational Health (FIOH) 2011, OP and FION 2012, OP, Terveystalo and FIOH 2014, Ossi Aura Consulting 2016, unpublished reports).

23. Johanson, U., Foldspang, L., Mark, M., Lund Rants, L., Römer Hjorth, L., Langholz-Carstenssen, C., Melchior Poulsen, O., Ahonen, G., Aasnæss, S. (2014). Working environment and productivity. A register-based analysis of Nordic enterprises. Copenhagen: Nordic Council of Ministers. Series: TemaNord 2014:546. p. 87. ISSN 0908-6692. DOI: 10.6027/TN2014-546.

24. Aura, O., Ahonen, G., Hussi, T. (2015). Henkilöstö-tuottavuus ja eurot - case rakennusala. Helsinki: Keskinäinen Eläkevakuutusyhtiö Etera.

25. Lindström, K., Schrey, K., Ahonen, G., och Kaleva, S. (2000). The Effects of Promoting Organizational Health on Personnel Well-Being and Effectiveness in Small and Medium-Sized Enterprises. In book: Healthy and Productive Work: An International Perspective (Eds. Murphy, L. and Cooper, C.). Taylor \& Francis, London: CRC Press, https://doi.org/10.4324/9780203305645.

26. Aura, O., Ahonen, G., Ilmarinen, J. (2010). Toward Better Work and Well-being proceedings: Strategic Wellness Management in Finland The First National Survey of the Management of Employee Well-being. Journal of Occupational and Environmental Medicine, 52(12), 1249-1254.

27. Rissanen, M., Kaseva, E. (2014). Cost of lost labour input. Finland: Ministry of Social Affairs and Health, Department for Occupational Safetyand Health. Available: https://valtioneuvosto.fi/documents/1271139/1332445/Cost+of+lost+labour+input_en.pdf/d5790088-8e3e-4d13-a5cd$56 \mathrm{c} 23 \mathrm{~b} 67 \mathrm{de} 0 \mathrm{c} /$ Cost+of+lost+labour+input_en.pdf.pdf.

\section{Г. Ахонен}

ПРИНЦИПЫ УСИЛЕНИЯ ФИНАНСОВОГО СОДЕЙСТВИЯ БЛАГОПОЛУЧИЮ НА РАБОТЕ - ВЗГЛЯД ФИНЛЯНДИИ

Несмотря на многочисленные исследования, которые свидетельствуют о том, что содействие благополучию на работе в основном выгодно для компаний (организаций, учреждений), руководство многих из них не видит финансового потенциала улучшения условий труда своих сотрудников. Цель статьи - предоставить недавно полученные выводы о финансовых последствиях деятельности, связанной с благополучием на работе, в основном в Финляндии, и выделить пять принципов успеха в этом контексте. Это исследование основано на ряде эмпирических исследований, в которых автор статьи принимал участие в течение последнего десятилетия, а также на аналогичных исследованиях, как в Финляндии, так и в других странах. Основное внимание уделяется взаимосвязи между деятельностью, способствующей благополучию на работе, и ее финансовыми последствиями для работодателей. В частности, используются результаты десятилетнего финского проекта стратегического благополучия. Были собраны и проанализированы данные опросов более чем 2000 рандомизированных частных и государственных организаций Финляндии. Примеры в Финляндии показывают, что компании могут получить до 20 \% прибыли, инвестируя в свой персонал. Комплексные опросы в Финляндии показывают, что управление благополучием на рабочем месте не оптимально и что компании, которые хорошо заботятся о своих сотрудниках, преуспевают в финансовом отношении. Утверждается, что компании имеют ограниченное представление о масштабах и возможностях деятельности по обеспечению благополучия на работе и поэтому не видят ее финансового потенциала. Основным ограничением этого исследования является то, что оно основано в основном на данных исследований финских и других североевропейских стран. Это означает, что некоторые структуры расходов исследованных компаний могут отличаться от структур компаний в других странах. Однако масштабы финансовых последствий столь велики, что результаты могут быть показательными и для стран, где не проводилось исследование. Практическая ценность принципов, сформулированных и представленных в этом документе, состоит в том, что они демонстрируют механизмы того, как содействие безопасности и благосостоянию на работе трансформируется в финансовую ценность. Это может помочь государственным и частным лицам, которые определяют политику корпорации (организации, учреждения) в разработке кадровых стратегий на национальном уровне и на уровне компаний. Полученные результаты дополняют литературу об экономической целесообразности обеспечения безопасности и гигиены труда, предоставляя новые объяснения того, как возникают экономические эффекты.

Ключевые слова: охрана труда; укрепление здоровья на рабочем месте; хорошее самочувствие на работе; продуктивность; экономическая целесообразность; управление человеческими ресурсами. 